\title{
Synthesis and spectral studies of some $N-[(E)$-phenylmethylidene]benzenesulfonamides
}

\author{
K. G. Sekar ${ }^{1, *}$, G. Thirunarayanan ${ }^{2}$ \\ 1Department of Chemistry, National College, Tiruchirappalli-620 001, India. \\ ${ }^{2}$ Department of Chemistry, Annamalai University, Annamalainagar-608002, India. \\ *E-mail address: drkgsekar@yahoo.co.in
}

\begin{abstract}
A series of some $N-[(E)$-phenylmethylidene]benzenesulfonamide derivatives have been synthesised using solid $\mathrm{SiO}_{2}-\mathrm{H}_{3} \mathrm{PO}_{4}$ catalyst under solvent free conditions in microwave irradiation. The synthesised $E$-N-benzene sulfonilimines purities have been verified by their physical constants and spectroscopic data. The spectral frequencies are correlated with Hammett substituent constants, F and $\mathrm{R}$ parameters using linear regression analysis. From the results of statistical analysis the effect of substituents on the group frequencies will be discussed.
\end{abstract}

Keywords: $N$-[(E)-phenylmethylidene $]$ benzenesulfonamides; $\mathrm{SiO}_{2}-\mathrm{H}_{3} \mathrm{PO}_{4}$; Greener synthesis; Hammett correlations

\section{INTRODUCTION}

The $E$-N-benzene sulfonilimines are versatile useful intermediates for organic synthesis [1]. These imines possesses the $-\mathrm{CH}=\mathrm{N}-\mathrm{SO}_{2}-$ moiety and this is bonded with alkyl - aryl or aryl- aryl groups in both sides. N-tosylimine intermediates are used as excellent substrates in Diels-Alder reactions and it is called as Aza-Diels-Alder reaction [2]. In this Diels-Alder reactions this itermediates undergo nucleophilic additions [3,4], reductions [5], radical [6] and Baylis- Hillman [7,8]. Generally, these $E$-N-benzene sulfonilimines were prepared by condensation of aldehydes and $\mathrm{N}$-tosylamines using several methods such as conventional solvent assisted condensation $[9,10]$, green methods, like microwave assisted condensation [11], isomerization of $\mathrm{N}$-tosylaziridines by palladium [12], tellurium metal assisted oxidation of chloramine $\mathrm{T}$ [9], rearrangement of oxime O-sulfinates by in situ $[13,14]$, reaction of $\mathrm{N}$ trimethylsilylaldimine and solfonyl chlorides [15] and condensation of racemic sulfinylamides with carbonyl compounds followed by oxidation with haloperoxobenzoic acid [16]. For this condensation various catalyst have been utilized such as, $\mathrm{TiCl}_{4}$ [17], aq. $\mathrm{HCOOH}$ and $\mathrm{Na}_{2} \mathrm{CO}_{3}$ [18], Molecular sieves-amberlite [19], claymineral [20], zeolites [7], Lewis acid, protoic acids, base, metal oxides, $\mathrm{AlCl}_{3}$ [21], $\mathrm{BF}_{3}-\mathrm{Et}_{2} \mathrm{O}$ [22], sulfamic acid [23], $\mathrm{P}_{2} \mathrm{O}_{5} / \mathrm{SiO}_{2}$ [24], tetraethyl orthosilicate [25], silphox [26], zirconium sulphate-silica [27], sulfated titania [28], montmorillonite K-10 [29], zirconium oxide-persulfate [30], powdered zinc oxide [31], TFFA [32], $\mathrm{InCl}_{3}$ [10] and ionic liquids [33], This E-N-benzene sulfonilimines have been used for synthesis of many organics such as triheteroarylmethanes 
[2], stereoselective heterocycles [1], co-ordination compounds [34], porphyrins [35], azetidine-2-imines [36], pyrrolidines [37], multisubstituted imidazolidines [38], $\alpha, \beta$-diamino acid derivatives [39], aziridines [40], Chiral aziridines [41], (Z)-N-(1-bromo-1-alken-2-yl)-ptoluenesulfonamides [3], Tosylamino alkyl naphthalenols [42], vinyl aziridines [43], 2Benzoylfumarates and 1-Aza dienes [44], complexes containing nitroamines [45], arylgylcene derivatives [46], 2-alikylidenazetidines [47], chiral 1-aryl-1-ethylamines [48], heteroaromatic N-tosyl $\alpha$-amino acids [49], carboxylates [50], tosylhexahydropyrimidine-2imines [51], $\beta$-aryl- $\beta$-amino acids [52], furyl sulphonamides [53], Baylis-Hillman adducts [8], imidazoles [11], and sulphonamide phosphonates [54]. Solvent free methods are very useful for synthesis of various organics [11,55-57].

Organic Chemists and researcher have paid more attention to green synthesis, due to the operational simplicity, lesser times, high yields, easy handling procedure and less hazardous to reaction and environment. The spectroscopic data is useful for analysis ground state molecular equilibration and configuration of organic molecules [58-61]. Also these findings were carried out via spectral correlations. The spectral group frequencies were correlated various substituent constants and $\mathrm{F}$ and $\mathrm{R}$ parameters gave the effects of the substituents on the group frequency of the corresponding molecule.

This type of study was studied only in ketones, esters, imines, acyl halides, pyrazolines, unsaturated aldehydes and acids [62-66]. With a view to above, there is no report available in the literature for solvent free synthesis and the study of effects of substituent on the group frequencies of some $E$-N-benzene sulfonilimines by $\mathrm{SiO}_{2}-\mathrm{H}_{3} \mathrm{PO}_{4}$ catalyzed condensation of aldehydes and sulphonamides. Therefore the authors have taken efforts to synthesis of some $E$-N-benzene sulfonilimines and studied the spectral correlations on the specified group frequencies using Hammett correlation equation.

\section{EXPERIMENTAL}

\section{1. Materials and Methods}

All chemicals used were purchased from Sigma-Aldrich and E-Merck chemical companies. Infrared spectra $\left(\mathrm{KBr}, 4000-400 \mathrm{~cm}^{-1}\right)$ were recorded on AVATAR-300 Fourier transform spectrophotometer. The NMR spectra of all $E$-N-benzene sulfonilimines were recorded in INSTRUM AV300 NMR spectrometer operating at $500 \mathrm{MHz}$ for ${ }^{1} \mathrm{H}$ and 125.46 $\mathrm{MHz}$ for ${ }^{13} \mathrm{C}$ spectra in DMSO solvent using TMS as internal standard. Mass spectra were recorded on a SIMADZU GC-MS2010 Spectrometer using Electron Impact (EI) techniques.

\section{2. Synthesis of $\mathrm{SiO}_{2}-\mathrm{H}_{3} \mathrm{PO}_{4}$ catalyst}

The $\mathrm{SiO}_{2}-\mathrm{H}_{3} \mathrm{PO}_{4}$ catalyst was prepared by procedure published in literature [55].

\section{3. Synthesis of $E$-N-benzene sulfonilimines}

To an appropriate mixture of substituted benzaldehydes (2 mmol), benzene sulphonamide ( $2 \mathrm{mmol}$ ) and $0.5 \mathrm{~g}$ of $\mathrm{SiO}_{2}-\mathrm{H}_{3} \mathrm{PO}_{4}$ were taken in $50 \mathrm{~mL}$ glass beaker and covered with lid. This mixture was subjected to microwave heating for 5-8 minutes at $650 \mathrm{~W}$ (Samsung GW73BD microwave oven, 100-750 W, $230 \mathrm{~V}$ A/C, $2450 \mathrm{MHz}$ ). The completion of the reaction was monitored by thin layer chromatography. After completion of reaction, dichloromethane $(20 \mathrm{~mL})$ was added, followed by simple filtration. 
The pure product was obtained by the evaporation of dichloromethane and recrystallization with ethanol. The yields of the $E$-N-benzene sulfonilimines are more than 90 $\%$. The purities of these $E-\mathrm{N}$-benzene sulfonilimines were persuade by their physical constants, IR, ${ }^{1} \mathrm{H},{ }^{13} \mathrm{C}$ NMR and Mass spectral data. Analytical and mass spectral data are presented in Table 1.<smiles>[X]c1ccc(C([CH2+])=O)cc1</smiles>

$\mathrm{X}=\mathrm{H}, 3-\mathrm{Br}, 4-\mathrm{Br}, 2-\mathrm{Cl}$, 4-Cl, 2-F, 4- $-\mathrm{OCH}_{3}, 4-\mathrm{CH}_{3}, 4-\mathrm{NO}_{2}$

Scheme 1. Synthesis of substituted aryl $E$-N-benzene sulfonilimines.

Table 1. Analytical, Physical constants and mass fragment data of $E-\mathrm{N}-$ benzene sulfonilimines.

\begin{tabular}{|c|c|c|c|c|c|c|}
\hline $\begin{array}{c}\text { Ent } \\
\text { ry }\end{array}$ & $\mathbf{X}$ & $\mathbf{M}$. F. & $\mathbf{M}$. W. & $\begin{array}{c}\text { Yield } \\
\mathbf{( \% )}\end{array}$ & $\mathbf{m . ~ p . ~}\left({ }^{\circ} \mathbf{C}\right)$ & Mass (m/z) \\
\hline 1 & $\mathrm{H}$ & $\mathrm{C}_{13} \mathrm{H}_{11} \mathrm{NO}_{2} \mathrm{~S}$ & 245 & 94 & $\begin{array}{c}83-84 \\
(80-82)[33]\end{array}$ & $245[\mathrm{M}+]$ \\
\hline 2 & $3-\mathrm{Br}$ & $\mathrm{C}_{13} \mathrm{H}_{10} \mathrm{BrNO}_{2} \mathrm{~S}$ & 325 & 91 & $111-112$ & $\begin{array}{c}324\left[\mathrm{M}^{+}\right] \\
326\left[\mathrm{M}^{+2}\right]\end{array}$ \\
\hline 3 & $4-\mathrm{Br}$ & $\mathrm{C}_{13} \mathrm{H}_{10} \mathrm{BrNO}_{2} \mathrm{~S}$ & 325 & 93 & $\begin{array}{c}199-200 \\
(198-204)[33]\end{array}$ & $\begin{array}{c}325\left[\mathrm{M}^{+}\right], \\
327\left[\mathrm{M}^{+2}\right]\end{array}$ \\
\hline 4 & $2-\mathrm{Cl}$ & $\mathrm{C}_{13} \mathrm{H}_{10} \mathrm{ClNO}_{2} \mathrm{~S}$ & 279 & 91 & $\begin{array}{c}135-136 \\
(132-136)[33]\end{array}$ & $\begin{array}{c}279\left[\mathrm{M}^{+}\right] \\
281\left[\mathrm{M}^{+2}\right]\end{array}$ \\
\hline 5 & $4-\mathrm{Cl}$ & $\mathrm{C}_{13} \mathrm{H}_{10} \mathrm{ClNO}_{2} \mathrm{~S}$ & 279 & 91 & $\begin{array}{c}129-130 \\
(128-132)[33]\end{array}$ & $\begin{array}{c}279\left[\mathrm{M}^{+}\right] \\
281\left[\mathrm{M}^{+2}\right]\end{array}$ \\
\hline 6 & $2-\mathrm{F}$ & $\mathrm{C}_{13} \mathrm{H}_{10} \mathrm{FNO}_{2} \mathrm{~S}$ & 263 & 90 & $\begin{array}{c}124-125 \\
(119-125)[33]\end{array}$ & $\begin{array}{c}263\left[\mathrm{M}^{+}\right] \\
265\left[\mathrm{M}^{+2}\right]\end{array}$ \\
\hline 7 & $4-$ & $\mathrm{C}_{14} \mathrm{H}_{13} \mathrm{NO}_{3} \mathrm{~S}$ & 275 & 94 & $\begin{array}{c}133-134 \\
(130-134)[33]\end{array}$ & $275\left[\mathrm{M}^{+}\right]$ \\
\hline 8 & $4-\mathrm{CH}_{3}$ & $\mathrm{C}_{14} \mathrm{H}_{13} \mathrm{NO}_{2} \mathrm{~S}$ & 259 & 92 & $\begin{array}{c}112-113 \\
(110-112)[33]\end{array}$ & $259\left[\mathrm{M}^{+}\right]$ \\
\hline 9 & $4-\mathrm{NO}_{2}$ & $\mathrm{C}_{14} \mathrm{H}_{13} \mathrm{~N}_{2} \mathrm{O}_{4} \mathrm{~S}$ & 290 & 90 & $\begin{array}{c}113-114 \\
(110-112)[33]\end{array}$ & $290\left[\mathrm{M}^{+}\right]$ \\
\hline
\end{tabular}

\section{RESULTS AND DISCUSSION}

\section{1. Spectral linearity}

In the present study the Hammett spectral linearity of these synthesised $E$-N-benzene sulfonilimines has been studied by evaluating the substituent effects [61-66] on the group 
frequencies. The assigned spectroscopic data of all $E$-N-benzene sulfonilimines such as absorption infrared carbonyl stretches of $v \mathrm{C}=\mathrm{N}, v \mathrm{~S}=\mathrm{O},\left(\mathrm{cm}^{-1}\right)$, NMR chemical shifts $\delta(\mathrm{ppm})$ of $\mathrm{CH}, \mathrm{C}=\mathrm{N}$ have been assigned and these data are correlated with various substituent constants.

\section{1. 1. IR spectral study}

The assigned $\mathrm{C}=\mathrm{N}$ and $\mathrm{S}=\mathrm{O}$ frequencies $\left(\mathrm{cm}^{-1}\right)$ of synthesised $E$-N-benzene sulfonilimines of present study are tabulated in Table 2 . These data have been correlated with Hammett substituent constants [55-66] and Swain-Lupton constants [67] and are presented in Table 3. In this correlation the structure parameter Hammett equation employed is as shown in the following equation:

$$
v=\rho \sigma+v_{0}
$$

Where $v$ is the carbonyl frequencies of substituted system and $v_{0}$ is the corresponding quantity of unsubstitued system; $\sigma$ is a Hammett substituent constant, which in principle is characteristics of the substituent and $\rho$ is a reaction constant which is depend upon the nature of the reaction.

Table 2. Infrared stretches $\left(v, \mathrm{~cm}^{-1}\right)$ and NMR chemical shifts $(\delta$, ppm) of $E$-N-benzene sulfonilimines.

\begin{tabular}{|c|c|c|c|c|c|}
\hline \multirow{2}{*}{ Entry } & \multirow{2}{*}{$\mathbf{X}$} & \multicolumn{2}{|c|}{ IR } & ${ }^{\mathbf{1}} \mathbf{H}$ & ${ }^{\mathbf{1 3}} \mathbf{C}$ \\
\cline { 3 - 6 } & & $v \mathrm{C}=\mathrm{N}$ & $v \mathrm{~S}=\mathrm{O}$ & $\delta \mathrm{C}-\mathrm{H}$ & $\delta \mathrm{C}=\mathrm{N}$ \\
\hline 1 & $\mathrm{H}$ & 1658.25 & 1063.58 & 8.462 & 179.32 \\
\hline 2 & $3-\mathrm{Br}$ & 1657.98 & 1060.35 & 8.495 & 178.26 \\
\hline 3 & $4-\mathrm{Br}$ & 1658.04 & 1062.34 & 8.359 & 179.55 \\
\hline 4 & $2-\mathrm{Cl}$ & 1658.94 & 1062.52 & 8.401 & 179.02 \\
\hline 5 & $4-\mathrm{Cl}$ & 1657.92 & 1062.85 & 8.442 & 179.46 \\
\hline 6 & $2-\mathrm{F}$ & 1658.03 & 1062.38 & 8.325 & 179.65 \\
\hline 7 & $4-\mathrm{OCH}_{3}$ & 1657.02 & 1060.02 & 8.001 & 178.02 \\
\hline 8 & $4-\mathrm{CH}_{3}$ & 1658.07 & 1060.21 & 8.012 & 178.98 \\
\hline 9 & $4-\mathrm{NO}_{2}$ & 1659.03 & 1064.25 & 8.499 & 181.36 \\
\hline
\end{tabular}

The results of single parameter statistical analysis of $v \mathrm{C}=\mathrm{N}$ stretches with Hammett $\sigma$ and $\sigma^{+}$substituent constants gave satisfactory correlations. The Hammett $\sigma_{I}, \sigma_{R}$ and $R$ parameters were satisfactorily correlated with $v \mathrm{C}=\mathrm{N}$ stretches excluding $\mathrm{H}, 2-\mathrm{Cl}, 2-\mathrm{F}$ and 4- $\mathrm{CH}_{3}$ substituents. If these substituents were included in the correlation, the correlations were reduced significantly. The field effect components of the substituents were fail in correlation. All correlations gave positive $\rho$ values. This may mean that the normal substituent effect operates in all $E$-N-benzene sulfonilimines. The failure in correlation is due the conjugation between the substituent and the $\mathrm{C}=\mathrm{N}$ group in all $E-\mathrm{N}$-benzene sulfonilimines as shown in Figure 1.

The correlation of $\nu \mathrm{C}=\mathrm{S}$ stretches with Hammett $\sigma, \sigma^{+}$and $\sigma_{\mathrm{I}}$ substituent constants gave satisfactory $r$ values $\left[\sigma(r=0.906), \sigma^{+}(r=0.906)\right.$ and $\left.\sigma_{I}(r=0.903)\right]$ excluding $\mathrm{H}, 3-\mathrm{Br}$ and $4-\mathrm{CH}_{3}$ substituents. If these substituents were included in the correlation, the correlations were reduced significantly. The resonance and field effect components of the substituents were fail in correlations. While seeking the $\rho$ values, all correlation gave positive $\rho$ values 
and it is evident for the normal substituent effects operates in all systems. The failure in correlation is due the conjugation between the substituent and the $\mathrm{C}=\mathrm{N}$ group in all $E-\mathrm{N}-$ benzene sulfonilimines as shown in Figure 1.

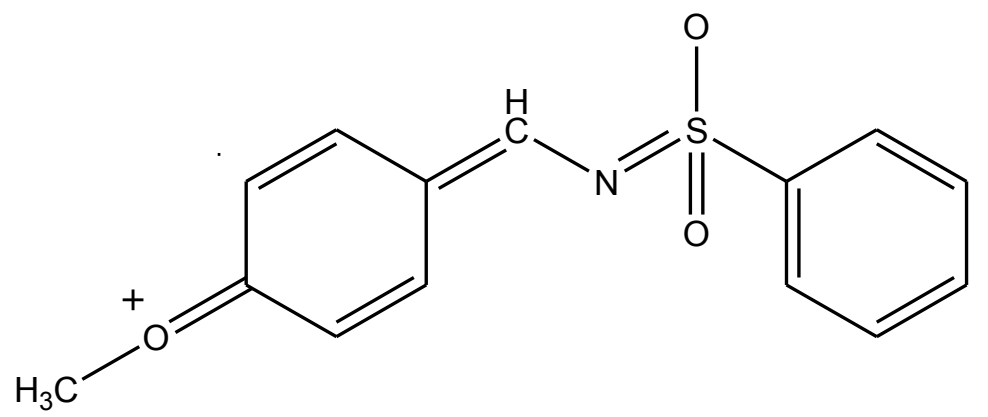

Figure 1. The resonance-conjugative structure.

In view of the inability of some of the $\sigma$ constants to produce individually satisfactory correlations, it was thought that worthwhile to seek multiple correlations involving either $\sigma_{\mathrm{I}}$ and $\sigma_{R}$ constants or Swain-Lupton's [67] $\mathrm{F}$ and $\mathrm{R}$ parameters. The correlation equations for $v \mathrm{C}=\mathrm{N}$ and $v \mathrm{C}=\mathrm{S}$ are given in equations 2-5.

$$
\begin{gathered}
\begin{array}{c}
\mathrm{C}=\mathrm{N}\left(\mathrm{cm}^{-1}\right)=1658.14( \pm 0.342)+0.902( \pm 0.071) \sigma_{\mathrm{I}}+1.875( \pm 0.081) \sigma_{\mathrm{R}} \\
(R=0.969, \mathrm{n}=9, \mathrm{P}>95 \%) \\
v \mathrm{C}=\mathrm{N}\left(\mathrm{cm}^{-1}\right)=1658.21( \pm 0.281)+1.000( \pm 0.060) \mathrm{F}+1.965( \pm 0.654) \mathrm{R} \\
(R=0.979, \mathrm{n}=9, \mathrm{P}>95 \%) \\
v \mathrm{C}=\mathrm{S}\left(\mathrm{cm}^{-1}\right)=1061.88( \pm 0.957)+2.468( \pm 0.243) \sigma_{\mathrm{I}}+4.097( \pm 1.249) \sigma_{\mathrm{R}} \\
(R=0.963, \mathrm{n}=9, \mathrm{P}>95 \%) \\
v \mathrm{C}=\mathrm{S}\left(\mathrm{cm}^{-1}\right)=1061.99( \pm 0.811)+2.839( \pm 1.446) \mathrm{F}+4.455( \pm 1.888) \mathrm{R} \\
(R=0.972, \mathrm{n}=9, \mathrm{P}>95 \%)
\end{array}
\end{gathered}
$$

\section{1. 2. ${ }^{1}$ H NMR spectral study}

Deuterated dimethylsulphoxie was used for recording the ${ }^{1} \mathrm{H}$ NMR spectra of synthesized $E$-N-benzene sulfonilimines employing tetramethylsilane (TMS) as internal standard. The $\mathrm{CH}$ protons signals of the $E$-N-benzene sulfonilimines were obtained as a singlet and assigned from their spectra. The assigned $\mathrm{CH}$ proton chemical shifts $\delta(\mathrm{ppm})$ of all $E$-N-benzene sulfonilimines were presented in Table 2. 
Table 3. Results of statistical analysis of infrared absorptions $\left(v, \mathrm{~cm}^{-1}\right)$ and NMR chemical shifts

$(\delta, \mathrm{ppm})$ of $E$-N-benzene sulfonilimines with Hammett $\sigma, \sigma^{+}, \sigma_{\mathrm{I}}, \sigma_{\mathrm{R}}$ and $\mathrm{F}$ and R parameters.

\begin{tabular}{|c|c|c|c|c|c|c|c|}
\hline Frequency & Constants & $\mathbf{r}$ & $\mathbf{I}$ & $\rho$ & $\mathbf{s}$ & $\mathbf{n}$ & Correlated derivatives \\
\hline \multirow[t]{6}{*}{$\begin{array}{l}\mathrm{vC}=\mathrm{N} \\
\left(\mathrm{cm}^{-1}\right)\end{array}$} & $\sigma$ & 0.906 & 1657.90 & 1.295 & 0.45 & 9 & $\begin{array}{c}\mathrm{H}, 3-\mathrm{Br}, 4-\mathrm{Br}, 2-\mathrm{Cl}, 4-\mathrm{Cl}, 2-\mathrm{F}, \\
4-\mathrm{OCH}_{3}, 4-\mathrm{CH}_{3}, 4-\mathrm{NO}_{2}\end{array}$ \\
\hline & $\sigma^{+}$ & 0.907 & 1657.97 & 0.941 & 0.45 & 9 & $\begin{array}{c}\mathrm{H}, 3-\mathrm{Br}, 4-\mathrm{Br}, 2-\mathrm{Cl}, 4-\mathrm{Cl}, 2-\mathrm{F}, \\
4-\mathrm{OCH}_{3}, 4-\mathrm{CH}_{3}, 4-\mathrm{NO}_{2}\end{array}$ \\
\hline & $\sigma_{\mathrm{I}}$ & 0.903 & 1657.84 & 0.824 & 0.59 & 7 & $\begin{array}{c}\text { 3-Br, 4-Br, 2-Cl, 4-Cl, 2-F, } \\
\text { 4-OCH } \mathrm{OCH}_{3}, 4-\mathrm{NO}_{2}\end{array}$ \\
\hline & $\sigma_{\mathrm{R}}$ & 0.905 & 1658.46 & 1.819 & 0.50 & 7 & $\begin{array}{c}\mathrm{H}, 3-\mathrm{Br}, 4-\mathrm{Br}, 4-\mathrm{Cl}, 4-\mathrm{OCH}_{3}, \\
\text { 4- } \mathrm{CH}_{3}, 4-\mathrm{NO}_{2}\end{array}$ \\
\hline & $\mathrm{F}$ & 0.802 & 1657.92 & 0.575 & 0.96 & 9 & $\begin{array}{c}\mathrm{H}, 3-\mathrm{Br}, 4-\mathrm{Br}, 2-\mathrm{Cl}, 4-\mathrm{Cl}, 2-\mathrm{F}, \\
\text { 4- } \mathrm{OCH}_{3}, 4-\mathrm{CH}_{3}, 4-\mathrm{NO}_{2}\end{array}$ \\
\hline & $\mathrm{R}$ & 0.906 & 1658.53 & 1.713 & 0.46 & 7 & $\begin{array}{c}\mathrm{H}, 3-\mathrm{Br}, 4-\mathrm{Br}, 4-\mathrm{Cl}, 4-\mathrm{OCH}_{3}, \\
\text { 4- } \mathrm{CH}_{3}, 4-\mathrm{NO}_{2}\end{array}$ \\
\hline \multirow[t]{6}{*}{$\begin{array}{l}v \mathrm{~S}=\mathrm{O} \\
\left(\mathrm{cm}^{-1}\right)\end{array}$} & $\sigma$ & 0.906 & 1061.51 & 2.984 & 1.28 & 7 & $\begin{array}{c}\text { 4-Br, 2-Cl, 4-Cl, 2-F, 4- } \mathrm{OCH}_{3}, \\
4-\mathrm{CH}_{3}, 4-\mathrm{NO}_{2}\end{array}$ \\
\hline & $\sigma^{+}$ & 0.906 & 1061.69 & 2.021 & 1.25 & 7 & $\begin{array}{c}\text { 4-Br, 2-Cl, 4-Cl, 2-F, 4-OCH } 3 \text {, } \\
\text { 4- } \mathrm{CH}_{3}, 4-\mathrm{NO}_{2}\end{array}$ \\
\hline & $\sigma_{\mathrm{I}}$ & 0.903 & 1061.22 & 2.297 & 1.52 & 7 & $\begin{array}{c}\mathrm{H}, 3-\mathrm{Br}, 4-\mathrm{Br}, 2-\mathrm{Cl}, 4-\mathrm{Cl}, 2-\mathrm{F}, \\
\text { 4- } \mathrm{OCH}_{3}, 4-\mathrm{NO}_{2}\end{array}$ \\
\hline & $\sigma_{\mathrm{R}}$ & 0.851 & 1062.75 & 3.946 & 1.41 & 9 & $\begin{array}{c}\mathrm{H}, 3-\mathrm{Br}, 4-\mathrm{Br}, 2-\mathrm{Cl}, 4-\mathrm{Cl}, 2-\mathrm{F}, \\
4-\mathrm{OCH}_{3}, 4-\mathrm{CH}_{3}, 4-\mathrm{NO}_{2}\end{array}$ \\
\hline & $\mathrm{F}$ & 0.831 & 1061.34 & 1.875 & 1.55 & 9 & $\begin{array}{c}\mathrm{H}, 3-\mathrm{Br}, 4-\mathrm{Br}, 2-\mathrm{Cl}, 4-\mathrm{Cl}, 2-\mathrm{F}, \\
4-\mathrm{OCH}_{3}, 4-\mathrm{CH}_{3}, 4-\mathrm{NO}_{2}\end{array}$ \\
\hline & $\mathrm{R}$ & 0.805 & 1062.91 & 3.739 & 1.34 & 9 & $\begin{array}{c}\mathrm{H}, 3-\mathrm{Br}, 4-\mathrm{Br}, 2-\mathrm{Cl}, 4-\mathrm{Cl}, 2-\mathrm{F}, \\
4-\mathrm{OCH}_{3}, 4-\mathrm{CH}_{3}, 4-\mathrm{NO}_{2}\end{array}$ \\
\hline \multirow[t]{6}{*}{$\begin{array}{c}\delta \mathrm{CH} \\
(\mathrm{ppm})\end{array}$} & $\sigma$ & 0.907 & 8.245 & 0.485 & 0.12 & 8 & $\begin{array}{c}\mathrm{H}, 3-\mathrm{Br}, 4-\mathrm{Br}, 2-\mathrm{Cl}, 4-\mathrm{Cl}, 2-\mathrm{F}, \\
\quad 4-\mathrm{OCH}_{3}, 4-\mathrm{CH}_{3}\end{array}$ \\
\hline & $\sigma^{+}$ & 0.908 & 8.275 & 0.322 & 0.12 & 8 & $\begin{array}{c}\mathrm{H}, 3-\mathrm{Br}, 4-\mathrm{Br}, 2-\mathrm{Cl}, 4-\mathrm{Cl}, 2-\mathrm{F}, \\
\text { 4-OCH }, 4-\mathrm{CH}_{3}\end{array}$ \\
\hline & $\sigma_{\mathrm{I}}$ & 0.905 & 8.173 & 0.444 & 0.17 & 7 & $\begin{array}{c}\text { 3-Br, 4-Br, 2-Cl, 4-Cl, 2-F, } \\
\text { 4- } \mathrm{CH}_{3}, 4-\mathrm{NO}_{2}\end{array}$ \\
\hline & $\sigma_{\mathrm{R}}$ & 0.845 & 8.414 & 0.461 & 0.18 & 9 & $\begin{array}{c}\mathrm{H}, 3-\mathrm{Br}, 4-\mathrm{Br}, 2-\mathrm{Cl}, 4-\mathrm{Cl}, 2-\mathrm{F}, \\
4-\mathrm{OCH}_{3}, 4-\mathrm{CH}_{3}, 4-\mathrm{NO}_{2}\end{array}$ \\
\hline & $\mathrm{F}$ & 0.804 & 8.210 & 0.320 & 0.18 & 9 & $\begin{array}{c}\mathrm{H}, 3-\mathrm{Br}, 4-\mathrm{Br}, 2-\mathrm{Cl}, 4-\mathrm{Cl}, 2-\mathrm{F}, \\
\text { 4- } \mathrm{OCH}_{3}, 4-\mathrm{CH}_{3}, 4-\mathrm{NO}_{2}\end{array}$ \\
\hline & $\mathrm{R}$ & 0.905 & 8.435 & 0.444 & 0.17 & 7 & $\begin{array}{c}\mathrm{H}, 3-\mathrm{Br}, 4-\mathrm{Br}, 2-\mathrm{Cl}, 4-\mathrm{Cl}, 2-\mathrm{F}, \\
\text { 4-NO } \mathrm{N}_{2}\end{array}$ \\
\hline \multirow[t]{6}{*}{$\begin{array}{l}\delta \mathrm{C}=\mathrm{N} \\
(\mathrm{ppm})\end{array}$} & $\sigma$ & 0.907 & 178.88 & 2.235 & 0.69 & 8 & $\begin{array}{l}\mathrm{H}, 4-\mathrm{Br}, 2-\mathrm{Cl}, 4-\mathrm{Cl}, 2-\mathrm{F}, \\
4-\mathrm{OCH}_{3}, 4-\mathrm{CH}_{3}, 4-\mathrm{NO}_{2}\end{array}$ \\
\hline & $\sigma^{+}$ & 0.906 & 179.05 & 1.333 & 0.75 & 8 & $\begin{array}{l}\mathrm{H}, 4-\mathrm{Br}, 2-\mathrm{Cl}, 4-\mathrm{Cl}, 2-\mathrm{F}, \\
4-\mathrm{OCH}_{3}, 4-\mathrm{CH}_{3}, 4-\mathrm{NO}_{2}\end{array}$ \\
\hline & $\sigma_{\mathrm{I}}$ & 0.904 & 178.66 & 1.744 & 0.92 & 7 & $\begin{array}{c}\text { 3-Br, 4-Br, 2-Cl, 4-Cl, 2-F, } \\
\text { 4- } \mathrm{OCH}_{3}, 4-\mathrm{NO}_{2}\end{array}$ \\
\hline & $\sigma_{\mathrm{R}}$ & 0.905 & 179.79 & 2.860 & 0.83 & 8 & $\begin{array}{l}\mathrm{H}, 3-\mathrm{Br}, 4-\mathrm{Br}, 2-\mathrm{Cl}, 4-\mathrm{Cl}, \\
4-\mathrm{OCH}_{3}, 4-\mathrm{CH}_{3}, 4-\mathrm{NO}_{2}\end{array}$ \\
\hline & $\mathrm{F}$ & 0.844 & 178.65 & 1.679 & 0.92 & 9 & $\begin{array}{c}\mathrm{H}, 3-\mathrm{Br}, 4-\mathrm{Br}, 2-\mathrm{Cl}, 4-\mathrm{Cl}, 2-\mathrm{F}, \\
4-\mathrm{OCH}_{3}, 4-\mathrm{CH}_{3}, 4-\mathrm{NO}_{2}\end{array}$ \\
\hline & $\mathrm{R}$ & 0.855 & 179.83 & 2.362 & 0.84 & 9 & $\begin{array}{c}\mathrm{H}, 3-\mathrm{Br}, 4-\mathrm{Br}, 2-\mathrm{Cl}, 4-\mathrm{Cl}, 2-\mathrm{F}, \\
\text { 4-OCH } \mathrm{OCH}_{3}, 4-\mathrm{CH}_{3}, 4-\mathrm{NO}_{2}\end{array}$ \\
\hline
\end{tabular}

$\mathrm{r}=$ correlation coefficient; $\mathrm{I}=$ intercept; $\rho=$ slope; $\mathrm{s}=$ standard deviation;

$\mathrm{n}=$ number of correlated derivative 
In nuclear magnetic resonance spectra, the proton or the ${ }^{13} \mathrm{C}$ chemical shifts $(\delta)$ depends on the electronic environment of the nuclei concerned. The assigned vinyl proton chemical shifts (ppm) have been correlated with reactivity parameters using Hammett equation in the form of

$$
\log \delta=\log \delta_{0}+\rho \sigma
$$

where $\delta_{0}$ is the chemical shift of unsubstitued ketones.

The assigned $\mathrm{CH}$ proton chemical shifts (ppm) are correlated with Hammett $\sigma$ constants and $\mathrm{F}$ and $\mathrm{R}$ parameters [55-66]. The results of statistical analysis [55-66] are presented in Table 3. The obtained correlations were satisfactory for $\mathrm{CH}$ chemical shifts with Hammett $\sigma, \sigma^{+}, \sigma_{\mathrm{I}}$ substituent constants and $\mathrm{R}$ parameters excluding $\mathrm{H}, 4-\mathrm{OCH}_{3}, 4-\mathrm{CH}_{3}$ and $4-\mathrm{NO}_{2}$ substituents. The Hammett $\sigma_{\mathrm{R}}$ constants and $\mathrm{R}$ parameters gave poor correlation. All correlation gave positive $\rho$ values and it is evident for the normal substituent effects operates in all correlations. The failure in correlation was due to the weak and incapable of resonance and field effects of substituents for prediction of the effects on the $\mathrm{CH}$ chemical shifts in all systems and it is associated with the resonance-conjugates structure shown in Figure 1.

Application of Swain-Lupton's [67] treatment to the relative chemical shifts ( $\delta, p p m)$ of $\mathrm{CH}$ with $\mathrm{F}$ and $\mathrm{R}$ values is successful with resonance, inductive effect generates the multi regression equations $7-8$.

$$
\begin{gathered}
\delta_{\mathrm{CH}}{ }^{(\mathrm{ppm})}=8.252( \pm 0.107)-0.462( \pm 0.220) \sigma_{\mathrm{I}}+0.489( \pm 0.281) \sigma_{\mathrm{R}} \\
(R=0.972, \mathrm{n}=9, \mathrm{P}>95 \%) \\
\delta_{\mathrm{CH}}{ }^{(\mathrm{ppm})}=8.0292( \pm 0.096)-0.440( \pm 0.027) \mathrm{F}+0.555( \pm 0.222) \mathrm{R} \\
(R=0.976, \mathrm{n}=9, \mathrm{P}>95 \%)
\end{gathered}
$$

\section{1. 3. ${ }^{13} \mathrm{C}$ NMR spectral study}

Physical organic chemists, researchers, organic chemists, spectral analysts, and scientists [55-66] have made extensive study of ${ }^{13} \mathrm{C}$ NMR spectral correlations of ketones, enones, acyl chlorides, bromides, esters, imines, pyrazolines and styrenes. The assigned vinyl $\mathrm{C}=\mathrm{N}$ carbon chemical shifts are presented in Table 2 . The results of statistical analysis are given in Table 3.

The $\mathrm{C}=\mathrm{N}$ chemical shifts (ppm) gave satisfactory correlation with Hammett substituent constants excluding 3-Br, $2-\mathrm{F}$ and $4-\mathrm{CH}_{3}$ substituents. All correlations produced positive $\rho$ values. This means that the normal substituent effect operates in all correlations. The $\mathrm{F}$ and $\mathrm{R}$ parameters were fail in correlation. This is due to reasons stated earlier with the resonance conjugative structure shown in Figure 1.

The Swain Lupton's [67] parameter correlations were satisfactorily obtained within these carbon chemical shifts and the regression equations are given in 9-10.

$$
\begin{gathered}
\delta \mathrm{C}=\mathrm{N}^{(\mathrm{ppm})}=179.14( \pm 0.521)+1.867( \pm 1.111) \sigma_{\mathrm{I}}+2.976( \pm 1.362) \sigma_{\mathrm{R}} \\
(R=0.973, \mathrm{n}=9, \mathrm{P}>95 \%) \\
\delta \mathrm{C}=\mathrm{N}^{(\mathrm{ppm})}=179.08( \pm 0.423)-2.317( \pm 0.911) \mathrm{F}+2.946( \pm 0.948) \mathrm{R} \\
(R=0.982, \mathrm{n}=9, \mathrm{P}>95 \%)
\end{gathered}
$$




\section{CONCLUSIONS}

We have synthesised more than $90 \%$ yield of some $E$-N-benzene sulfonilimines using a solid $\mathrm{SiO}_{2}-\mathrm{H}_{3} \mathrm{PO}_{4}$ acid catalyst by solvent free condensation of benzene solfonyl chloride and substituted benzaldehydes under microwave irradiation. The effects of substituent on the group frequencies $\left(v, \mathrm{~cm}^{-1}\right)$ such as $\mathrm{C}=\mathrm{N}, \mathrm{S}=\mathrm{O}$ and the chemical shifts $(\delta$, ppm) of $\mathrm{CH}$ and $\mathrm{C}=\mathrm{N}$ all the $E$-N-benzene sulfonilimines have been studied.

\section{References}

[1] Weinreb S. M., Topics in Curr. Chem. 190 (1997) 131-184.

[2] Temelli B., Tasgin D. I., Unaleroglu C., Tetrahedron 66(34) (2010) 6765-6768.

[3] Yamagishi M., Nishigai K., Hata T., Urabe H., Org. Lett. 13(18) (2011) 4873-4875.

[4] Ma Z., Zhao Y., Jiang N., Jin X., Wang J., Tetrahedron Lett. 43 (2002) 3209-3212.

[5] Hojo M., Murakami C., Fujii A., Hosomi A., Tetrahedron Lett. 40 (1999) 911-914

[6] Yamada K. I., Yamamoto Y., Maekawa M., Tomioka K., J. Org. Chem. 69 (2004) $1531-1534$.

[7] Wang K., Xing Z., Ma Y., Catal. Lett. 123 (2008) 129-134.

[8] Shi Y. L., Xu Y. M., Shi M., Advanced Synth. Catal. 346 (9-10) (2004) 1220-1230.

[9] Trost B. M., Marrs C., J. Org. Chem. 56 (1991) 6468-6470.

[10] Deng G. S., Zou J. Y., Sun T. F., Chin. Chem. Lett. 22(5) (2011) 511-514.

[11] Samanta S. K., Kylänlahti I., Yli-Kauhaluoma J., Bioorg Med Chem Lett. 15(16) (2005) 3717-3719.

[12] Wolfe J. P., Ney J. E., Org. Lett. 5 (2003) 4607-4710.

[13] Boger D. L., Corbett W. L., J. Org. Chem. 57 (1992) 4777-4780 .

[14] Sisko J., Weinreb S. M., J. Org. Chem. 55 (1990) 393-395.

[15] Georg G. I., Harriman G. C. B., Peterson S. A., J. Org. Chem. 60 (1995) 7366-7368.

[16] Ruano J. L. G., Aleman J., Cid M. B., Parra A., Org. Lett. 7 (2005) 179-182 .

[17] Wynne J. H., Price S. E., Rorer J. R., Synth. Commun. 33 (2003) 341-342.

[18] Chemla F., Hebbe V., Normant J. F., Synthesis. (2000) 75-76.

[19] Vishwakarma L. C., Stringer O. D., Davis F., Org Synth Coll VIII (1993) 546-549.

[20] Laszlo P, Science 235 (1987) 1473-1477.

[21] Sharghi H., Hosseini-Sarvari M., Ebrahimpourmoghaddam S., Arkivoc, 15 (2007) 255-264.

[22] McFarlane A. K., Thomas G., Whiting A., Tetrahedron Lett. 34 (1993) 2379-2382.

[23] Li Z., Ren X., Wei P., Honggui Wan, Shi Y., Ouyang P., Green Chem. 8 (2006) 433436.

[24] Hasaninejad A., Zare A., Shrghi H., Arkivoc. 11 (2008) 64-74. 
[25] Love B. E., Raje P. S., Willims T. C., Synlett. (1994) 493-494.

[26] Hasaninejad A., Zare J., Sulfur Chem. 28 (2007) 357-364.

[27] Geng L. J., Liu Y., Chin. J. Chem. 25 (2005) 1103-1106.

[28] Jin T. S., Feng G. L., Yang M. N., J. Chem. Res (S). 9 (2003) 591-594.

[29] Jin T. S., Yu M. J., Liu L. B., Synth. Commun. 36 (2006) 2339-2344.

[30] Jin T. S., Feng G. L., Yang M. N., Synth. Commun. 34 (2004) 1277-1283.

[31] Hoseini-Sarvari M., Sharghi H., Phosphorus, Sulfur and Silicon. 182 (2007) 21252130.

[32] Lee K. Y., Lee C. G., Kim J. N., Tetrahedron Lett. 44 (2003) 1231-1234.

[33] Ardhapure S. S., Siddiqui S. A., Tekales U., Ingle R. D., Shinde S. B., Pawar R. P., Eur. Chem. Bull. 2(6) (2013) 320-323.

[34] Gao F., Deng M., Qian C., Tetrahedron. 61(52) (2005) 12238-12243.

[35] Temelli B., Unaleroglu C., Tetrahedron. 65(10) (2009) 2043-2050.

[36] Van Camp A., Goossens D., Moya-Portugues M., Marchand-Brynaert J., Ghosez L., Tetrahedron Lett. 21(32) (1980) 3081-3084.

[37] Meng L. G., CAi P., Guo Q., Xue S., J. Org. Chem. 73(21) (2008) 84-91-8496.

[38] Wu X., Zhang J., Synthesis. 44(14) (2012) 2147-2154.

[39] Song G., Jin M., Li Z., Ouyanf P., Org. Biomol. Chem. 9 (2011) 7144-7150.

[40] Concellon J. M., Rodriguez-Solla H., Simal C., Org. Lett. 10 (2008) 4457-4460.

[41] Hayashi Y., Urushima T., Sakamoto D., Torri K., Ishikawa H., Chem.- A European J. 17(42) (2011) 11715-11718.

[42] Ravindra Reddy .C, Sindhu C., Nandan Kumar D., Krishnaiah M., Helvitica Chim, Acta. 94 (2) (2011) 289-292.

[43] Hou X-L., Yang X-F., Dai L-X., Chem. Commun. (1998) 747-748.

[44] Nair V., Sreekanth A. R., Abhilash N., Biju A. T., Reena Devi B., Menon R. S., Rath N. P., Srinivas R., Synthesis. (2003) 1895-1902.

[45] Zhou H., Peng D., Qin B., Hou Z., Liu X., Feng X., J. Org. Chem. 72(26) (2007) 10302-10304.

[46] Yamamoto Y., Takashi Y., Kurihara K., Miyaura N., Australian J. Chem. 64(11) (2011) 1447-1453.

[47] Lu H., Li C., Org. Lett. 8 92006) 5365-5367.

[48] Nishimura T., Yasuhara Y., Hayashi T., Org. Lett. 8 (2006) 979-981.

[49] Johannsen M., Chem. Commun. (1999) 2233-2234.

[50] Lu K., Kwon O., Org. Synthesis. 86 (2009) 212-220.

[51] Shutalev A. D., Fesenko A. A., Tetrahedron. 67(36) (2011) 6883-6888.

[52] Ma Z., Zhao Y., Jiang N., Jin X., Wang J., Tetrahedron Lett. 43(17) (2002) 32093214. 
[53] Pawda A., Zanka A., Cassidy M. P., Tetrahedron. 59(27) (2003) 4939-4944.

[54] Das B., Balasubramaniyam P., Krishnaiah M., Veeranjaneyulu B., Reddy G. C., J. Org. Chem. 74(11) (2009) 4393-4395.

[55] Janaki P., Sekar K. G., Thirunarayanan G., Org. Chem: An Indian J. 9(2) (2013) 6880.

[56] Thirunarayanan G., Vanangamudi G., Subramanian M., Org. Chem: An Indian J. 9(1) (2013) 1-16.

[57] Sakthinathan S. P., Suresh R., Mala V., Sathiyamoorthi K., Kamalakkannan D., Ranganathan K., Arulkumaran R., Vijayakumar S., Sundararajan R., Vanangamudi G., Thirunarayanan G., Int. Lett. Chem. Phys. Astro. 6 (2013) 77-90.

[58] Sathiyamoorthi K., Mala V., Suresh R., Sakthinathan S. P., Kamalakkannan D., Ranganathan K., Arulkumaran R., Sundararajan R., Vijayakumar S., Vanangamudi G., Thirunarayanan G., Int. Lett. Chem. Phys. Astro. 7(2) (2013)102-119.

[59] Sekar K. G., Thirunarayanan G., Int. Lett. Chem. Phys. Astro. 8(2) (2013) 160-174.

[60] Arulkumaran R., Vijayakumar S., Sundararajan R., Sakthinathan S. P., Kamalakkannan D., Suresh R., Ranganathan K., Vanangamudi G., and Thirunarayanan G., Int. Lett. Chem. Phys. Astro. 4 (2012) 17-38.

[61] Ranganathan K., Suresh R., Kamalakkannan D., Arulkumaran R., Sundararajan R., Sakthinathan S. P., Vijayakumar S., Vanangamudi G., Thirumurthy K., Mayavel P., Thirunarayanan G., Int. Lett. Chem. Phys. Astro. 4 (2012) 66-75.

[62] Subramanian M., Vanangamudi G., Thirunarayanan G., Spectrochim Acta 110A (2013) 116-123.

[63] Arulkumaran R., Vijayakumar S., Sundararajan R., Sakthinathan S. P., Kamalakkannan D., Suresh R., Ranganathan K., Rajakumar P. R., Vanangamudi G., Thirunarayanan G., Int. Lett. Chem. Phys. Astro. 5 (2013) 21-38.

[64] Thirunarayanan G., Vanangamudi G., Sathiyendiran V., Ravi K., Indian J. Chem. 50B (4) (2011) 593-604.

[65] Suresh .R, Kamalakkannan D., Ranganathan K., Arulkumaran R., Sundararajan R., Sakthinathan S. P., Vijayakumar S., Sathiyamoorthy K., Mala V., Vanangamudi G., Thirumurthy K., Mayavel P., Thirunarayanan G., Spectrochim. Acta 101A (2013) 239248.

[66] Sakthinathan S. P., Vanangamudi G., Thirunarayanan G., Spectrochim. Acta 95A (2012) 693-700.

[67] Swain C. G., Lupton E. C. Jr., J. Am. Chem. Soc. 90 (1968) 4328-4337. 